\title{
福祉有償運送サービス導入後の移動制約者の交通行動に影響を与える要因の分析* \\ Factor analysis about travel behavior of the limited mobility people after introduction of special transport service
}

\author{
松中 亮治**・谷口 守***・楠田 裕子**** \\ by Ryoji MATSUNAKA • Mamoru TANIGUCHI • Yuko KUSUDA
}

\section{1. 背景と目的}

わが国では, 1970 年ごろから，高㱓者や障害者などの 移動制約者を対象として，ボランティア団体による無償 移送サービスが提供されてきた ${ }^{1)}$. しかし，この移送サー ビスは福祉施設への送迎を主としたものであり，このよ うな移送サービスのみでは, 移動制約者の外出を十分に カバーすることはできず，移動制約者のモビリティは 年々，低下の一途をたどっている。このような状況のな か, 今後の高齢化社会に対応すべく, 2000 年に『交通バ リアフリー法』が施行され, 公共交通施設のバリアフリ 一化が進められた. しかし, 公共交通施設がいくら整備 されても, その場所までのアクセス手段が確保されなけ れば，移動制約者が公共交通施設を利用することは困難 である. そのため, 公共交通機関を補完する ST サービ ス導入に対する社会的要請は極めて大きいものとなって いるが, わが国においては, 移動制約者に対する ST サ 一ビスは, これまで普及していなかった. その要因の一 つとして, これまでは道路運送法第 80 条第 1 項で自家用 自動車は有償で運送の用に供することは原則として禁止 されており，移動制約者を対象とした運送においても NPO 団体や社会福祉法人等による有償運送は規制され ていたことが挙げられる.

この状況を打破するため, 2003 年 4 月, 国の構造改革 特別区域の一つとして, 岡山県等において, 道路運送法 第 80 条第 1 項の規制が緩和され，移動制約者を対象とし た NPO 等の非営利法人による有償運送が認められるこ とになった. さらに, 2004 年 4 月には, 特区のみならず, 全国において道路運送法第 80 条第 1 項の規制が緩和され, 非営利法人による福祉有償運送サービスの提供が可能と なった.

本研究では, 岡山市・倉敷市の地方振興局管内におい て, 2003 年 11 月時点で福祉有償運送サービスを実施して いた全 5 事業者に, 福祉有償運送サービスの利用者とし

\footnotetext{
*keywords:移動制約者, ST サービス, 交通行動, 要因分析

** 正会員 博(工) 岡山大学大学院環境学研究科

干700-8530 岡山市津島中 3-1-1 Tel • Fax 086-251-8921

*** 正会員 工博 岡山大学大学院環境学研究科

**** 学生会員岡山大学大学院自然科学研究科
}

て登録していた移動制約者を対象としてアンケート調査 を実施するとともに, 福祉有償運送サービスを提供して いる事業者の運行記録を収集・集計し，移動制約者の外 出目的や利用交通機関などの交通行動の実態を把握する. さらに, それらの結果を用いて, 移動制約者の外出頻度 や福祉有償運送サービス利用の有無といった, 害際の交 通行動の要因を定量的に明らかにすることを目的とする.

\section{2. 本研究の特徵}

これまでにも, 移動制約者の交通行動を対象とした研 究は多数行われている. 溝端 ${ }^{2)}$ は, 高齢者や身体障害者 を対象として, 送迎型の無償移送サービスを提供してい る施設に対して調查を実施し, 定時運行時のピーク・ト リップ量を算定するとともに, 各施設が個別に提供して いるサービスを統合した場合のメリット等について検討 している. また, 北川ら ${ }^{3)}$ は, 高齢者の潜在交通需要に 関する調査データを用いて, 高龄者をいくつかのモビリ ティグループに分け，それぞれのグループごとに交通施 策を評価している. 青島ら ${ }^{4)}$ は, 障害別に身体障害者の 外出頻度や交通目的, 手段分担率を比較し, 高龄者ほど モビリティが低く, 需要が潜在化する傾向が顕著に現れ ることを示している. しかし, これらの既存研究は, い ずれも ST サービスが提供されていない状況下において, 移動制約者の交通行動の実態を把握し, 分析したもので あり，新たにST サービスが導入された場合，移動制約者 の外出頻度や福祉有償運送サービス利用の有無といった 移動制約者の実際の交通行動に影響を及ぼす要因などに ついては，未だ明らかにされていない.これに対して, 本研究では, 福祉有償運送サービス導入後における移動 制約者の実際に行った外出日時や, 目的, 利用した交通 手段等の交通行動を調査し, 潜在交通需要がどの程度顕 在化したかを明らかにするとともに, 実際の交通行動に 影響を及ぼす要因を実証的に明らかにすることを目的と しており, これらの点は本研究の大きな特徴であるとい える. 


\section{3. アンケート調查の概要}

\section{（1） アンケート調査の概要}

本研究では, 岡山市・倉敷市地方振興局管内において 2003 年 11 月時点で事業認定を受けている全 5 事業者に, 福祉有償運送サービス利用者として登録していた移動制 約者 177 名を対象として, アンケート調查を実施し，調 查期間中の最近 1 週間，もしくは，最近 5 回の外出につ いて, その詳細を調査した. 本研究で実施したアンケー 卜調査の概要を表-1に示す．また，対象となっている事 業者の事業内容等を表-2 に示す。

なお，構造改革特別区域に認定された地域では，あら かじめ認定された事業者に福祉有償運送サービス利用者 として登録している会員を対象としてサービスが提供さ れており，その会員は，介護保険法に基づく要介護認定 者, 身体障害者手帳保持者, 肢体不自由者・内部障害者 (人 工透析等)・精神障害により独立した歩行が困難な者のう ち，単独では公共交通機関の利用が困難な移動制約者に 限定されている.

また, 補完調査として, 各事業者が福祉有償運送サ一

\section{表-1 アンケート調査の概要}

\begin{tabular}{|c|c|}
\hline 調査期間 & 平成15年11月末～12月末 \\
\hline \multirow{2}{*}{ 対象者 } & $\begin{array}{l}\text { 岡山市・倉敷市の地方整備局管内において } \\
\text { 事業認定を受けている全事羓者に福祉有 } \\
\text { 償運送サービス利用者として登録している移 } \\
\text { 動制約者 }\end{array}$ \\
\hline & {$\left[\begin{array}{c}\text { 各事業者のサービス開始月 } \\
8 \text { 月開始 } \cdot 1 \text { 事業者, } 9 \text { 月開始 } \cdot \cdot 2 \text { 事業者 } \\
10 \text { 月開始 } \cdot 1 \text { 事業者, } 12 \text { 月開始 } \cdot 1 \text { 事業者 }\end{array}\right.$} \\
\hline 調査項目 & $\begin{array}{l}\text { (1)個人属性について } \\
\text { ·家族の送迎の有無...等 } \\
\text { (2)最近の交通行動について } \\
\text { ·外出日時 ·外出目的 } \\
\text { ·外出所要時間 } \\
\quad \text { ·利用可能な交通機関 } \\
\text { ·実際に利用した交通機関 } \\
\text { (3)福祉有償運送サービスに対する意識 }\end{array}$ \\
\hline 配布枚数 & 177部 \\
\hline 回収枚数 & 132部(回収率:74.6\%) \\
\hline
\end{tabular}

ビスを提供した際に運送時間や利用目的などを記載して いる運行記録を，アンケート期間に合わせて収集し，集 計した. 運行記録の主な集計項目を表-3に示す。

\section{（2）基礎集計結果}

本節では，前節で述ベたアンケート調査の基礎集計結 果について述べる。

\section{（a） 移動制約者の外出目的}

移動制約者の外出目的を図-1 に示寸.なお, 各外出目的 において,介護保険等の適用を問う設問を設けていない ため, 把握できない: 図-1に示すように，移動制約者の外 出目的の約 70\%が『通院』もしくは『通所』であり，『買 、物』や『娛楽・レジャー』を目的とする外出は，全体 の $11 \%$ と低くなっている. また，運行記録の集計結果か ら，福祉有償運送サービス利用時の利用目的を集計した ものを図-2 に示す．ただし，図-1の外出目的との整合を 図るため, 帰宅目的の利用は除外している．福祉有償運 送サービスは，介護保険が適用されない『買い物』や『娛 楽・レジャー』等の目的で移動制約者が外出する際の移 動手段を提供するために導入されており，サービスを提 供する際，利用目的は特に限定されていない，しかし， 図-1 に示す外出全体に占める『買い物』や『娛楽・レジ ヤー』目的の割合と比較すると，図-2 に示す福祉有償運

\section{表-3 運行記録集計の概要}

\begin{tabular}{|c|c|}
\hline 収集期間 & 平成15年11月末～12月末 \\
\hline & $\begin{array}{l}\text { 岡山市・倉敷市の地方整備局管内において } \\
\text { 事業認定を受けている王事羓者 }\end{array}$ \\
\hline 対象者 & {$\left[\begin{array}{c}\text { 各事業者のサービス開始月 } \\
8 \text { 月開始 } \cdot 1 \text { 事業者, } 9 \text { 月開始 } \cdot \cdot 2 \text { 事業者 } \\
10 \text { 月開始 } \cdot \cdot 1 \text { 事業者, } 12 \text { 月開始 } \cdot 1 \text { 事業者 }\end{array}\right]$} \\
\hline 記載項目 & 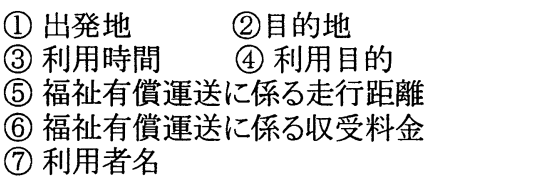 \\
\hline 集計項目 & $\begin{array}{l}\text { 1. 福祉有償運送の利用時間帯 } \\
\text { 2. 福祉有償運送の利用目的 }\end{array}$ \\
\hline
\end{tabular}

表-2 アンケート対象事業者の福祉有償運送料金体系と事業内容

\begin{tabular}{|c|c|c|c|c|c|}
\hline 法人名 & 法人A & 法人B & 法人C & 法人D & 法人E \\
\hline 事業開始月 & 8月 & 9月 & 9月 & 10 月 & 12 月 \\
\hline 種別 & 社会福祉法人 & NP0法人 & 社会福祉法人 & 社会福祉法人 & 社会福祉法人 \\
\hline & 距離制 $120 \mathrm{M} / \mathrm{km}$ & 距離制 100 円 $/ \mathrm{km}$ & 距離制 $100 \mathrm{M} / \mathrm{km}$ & 距離制 $120 \mathrm{~m} / \mathrm{km}$ & 距離制 100 円 $/ \mathrm{km}$ \\
\hline 料金体系 & 待機料金あり & 待機料金あり & 待機料金あり & $\begin{array}{l}\text { 時間制 } 1,000 \sim \\
1,260 \text { 円 } / 30 \text { 分 }\end{array}$ & 待機料金あり \\
\hline & & & & 待機料金あり & \\
\hline 事業内容 & $\begin{array}{l}\text { ·特別養護老人ホーム } \\
\text { ·身体障害者療養施設 } \\
\text { ·在宅サービス } \\
\text { ·ケアハウス } \\
\text { ・グループホーム }\end{array}$ & - 共同作業所 & ・ケアハウス & $\begin{array}{l}\text { ・介護老人保健施設 } \\
\text { ·在宅介護支援センターシ } \\
\text { ·訪問介護ステーション } \\
\text { ・ ケアハウス } \\
\text { ・グループホーム }\end{array}$ & $\begin{array}{l}\text { ·特別養護老人ホーム } \\
\text { ·在宅介護支援センター } \\
\text { ·老人保健施設 } \\
\text { · デイサービスセンター } \\
\text { · ケアハウス } \\
\text { ·グループホーム }\end{array}$ \\
\hline
\end{tabular}


送サービスを利用した外出に占める『買い物』や『娛楽・ レジャー』目的の割合の方が大きくなっているものの, 図-2 に示すように福祉有償運送サービスを利用する外出 においても『通院』目的の利用が半数以上を占めている のが現状である.

\section{（b）福祉有償運送サービスの利用時間帯}

福祉有償運送サービス利用時間帯の内訳を図-3に示寸， 図-3 に示すように, 福祉有償運送サービスの利用は午前 中に集中している. また, 図中の塗りつぶした部分は『通 院』目的の利用を表しており，午前中など特定の時間帯 に偏るのではなく, いずれの時間帯においても『通院』 目的の占める割合が大きいことが明らかになった。

\section{（c）外出時の利用交通機関}

移動制約者の外出時の利用交通機関を図-4に示寸．図

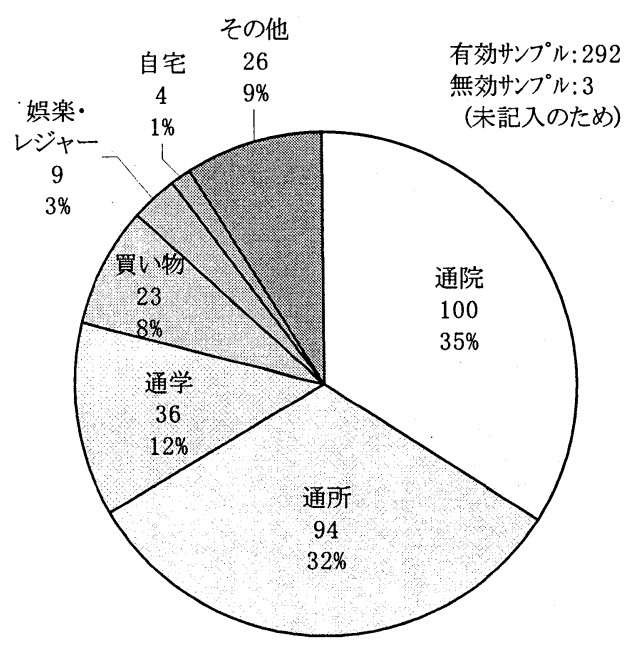

図-1 外出目的

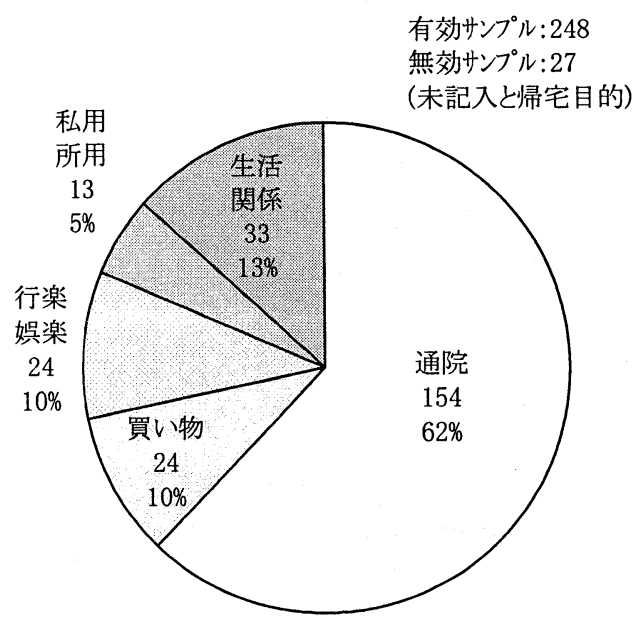

図-2 福祉有償運送サービスの利用目的
-4 に示すように, 『施設の送迎』や『家族の送迎』が全体 の約半数を占めている. 一方, 公共交通機関を利用した 移動制約者は全体の約 4\%に留まっている. また, 福祉有償 運送サービスと競合関係にある, 介護タクシーを利用し た移動制約者と, 福祉有償運送サービスを利用した移動 制約者の割合は, 福祉有償運送サービスを利用した移動 制約者の割合の方が大きくなっている.さらに,タクシー 全般(介護タクシー・福祉車両タクシーを含む)を利用し た移動制約者と, 福祉有償運送サービスを利用した移動 制約者の割合は，ほぼ同程度であり，事業開始からわず か 4 ケ月で福祉有償運送サービスは, 『家族の送迎』や『施 設の送迎』に次ぐ主要な交通機関として利用されている ことが伺われる.

\section{（d）福祉有償運送サービス利用の有無}

福祉有償運送サービス利用状況を図 -5 に示寸. 図-5に 示すように，福祉有償運送サービスを利用したことがあ る登録者は全体の約 32\%に留まっている.これは, 図-6 に示すように, 福祉有償運送サービスに登録した理由と して,『登録だけはしておこうと思った』、『家族にす寸め

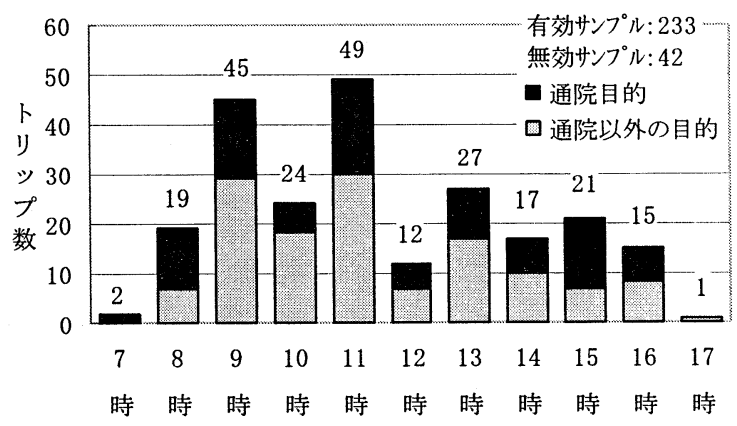

図-3 福祉有償運送サービスの利用時間帯

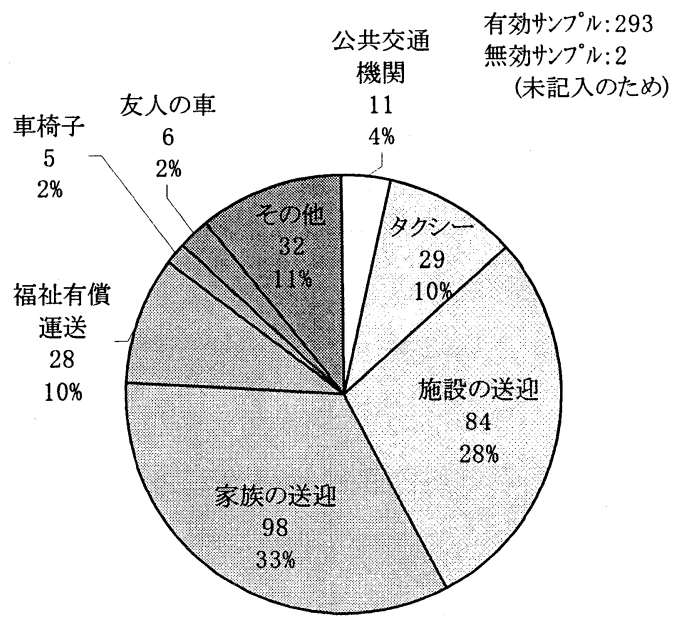

図-4 外出時の利用交通機関 
られたから』，『知人にす寸められたから』，『施設の人に すすめられたから』を挙げている回答者が全体の約 60\% を占めていることが原因の一つと考えられる.

\section{（e）福祉有償運送サービス利用時の代替交通機関}

表-1 に示寸調査項目(2)において, 実際に福祉有償運送 サービスを利用したと回答している被験者に対しては, 福祉有償運送サービスが無かった場合の代替交通機関も 併せて尋ねている. その結果を図-7 に示す. 図-7に示す ように，福祉有償運送サービスが無かった場合，46\%の 移動制約者が代替交通機関として，タクシーを利用する と回答している.

また，設問内にはタクシ一等の交通機関のほか，『外出 しなかった』もしくは『誰かに頼んだ』という選択肢を 設けており，福祉有償運送サービスを利用した回答者が これらの選択肢に回答した場合，これは，福祉有償運送 サービスが導入されたことによって新たに顕在化した外 出であると考えられる. このような考え方によって，外 出増加率を算出した結果, 福祉有償運送サービス導入に よる移動制約者の外出は，福祉有償運送サービス導入以 前に比べて約 1.4\%増加していることが明らかになった.

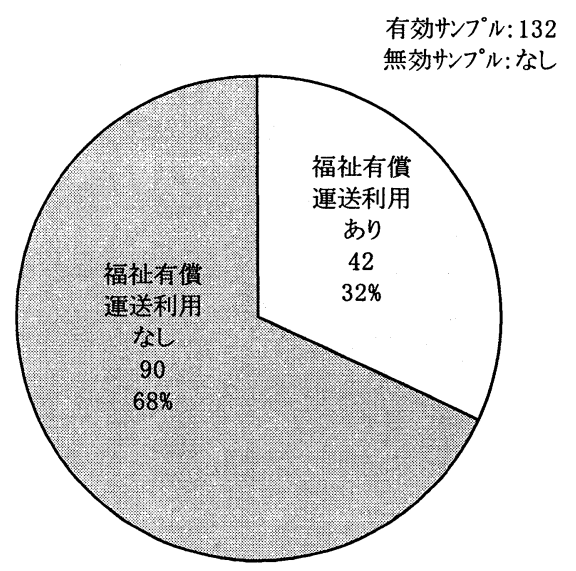

図-5 福祉有償運送サービス利用の有無

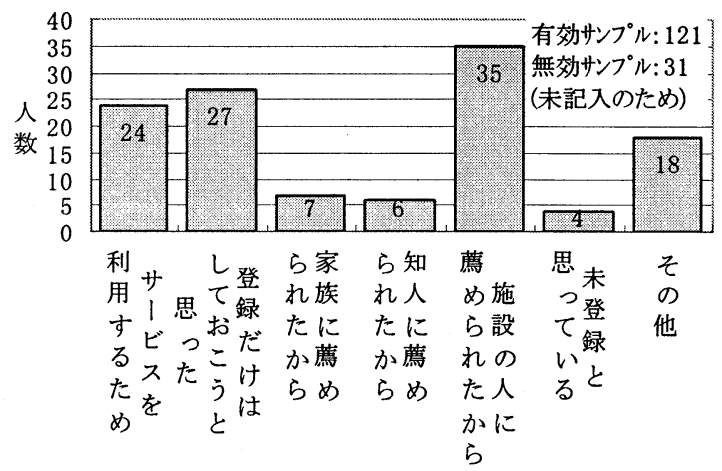

図-6＼cjkstart福祉有償運送サービスに登録した理由 （f） 福祉有償運送サービス導入後の生活の変化

福祉有償運送サービス導入後の移動制約者の生活の変 化を図-8に示す. 図-8に示すように, 福祉有償運送サ一 ビス導入後移動制約者の生活で最も変化した項目は,『家 族の負担が減った』である。これは，福祉有償運送サー ビス導入の目的のひとつである，家族負担の軽減につい ては，福祉有償運送サービスの導入により一定の効果が あったことを示す結果であるといえる.

\section{（g）まとめ}

『買い物』や『娛楽・レジャー』目的の外出割合は，移 動制約者の外出全体に占める割合より，福祉有償運送少 一ビスを利用した割合の方が大きくなっている. しかし， 福祉有償運送サービスを利用した場合においても，『通 院』目的の外出は利用目的全体の半数以上を占めている のが現状である，一方で，福祉有償運送サービス導入後 の移動制約者の生活の変化については, 『家族の負担が減 った』という回答が最も多く, 福祉有償運送サービス導 入の目的のひとつである，家族負担の軽減については一

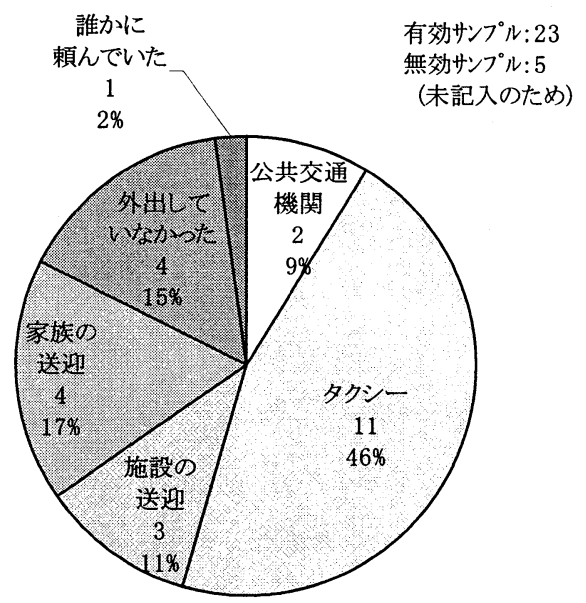

図-7 福祉有償運送サービス利用時の 代替交通機関

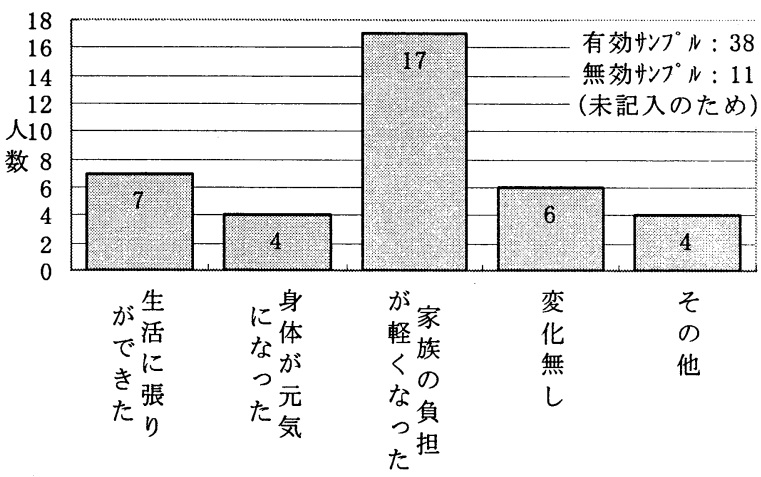

図-8 福祉有償運送サービス導入後の 生活の変化 
定の効果があったと考えられる.

また，外出時に利用した交通機関については，『施設の 送迎』, 『家族の送迎』が外出全体の約半数を占めている ものの, 『福祉有償運送サービス』と『タクシー』の利用 割合はほぼ同程度であり,『福祉運送有償サービス』は移 動制約者にとって『施設の送迎』や『家族の送迎』に次 ぐ主要な交通機関となりつつあると考えられる.

さらに, 移動制約者の外出増加率を算出した結果, 移 動制約者の外出は, 福祉有償運送サービス導入以前に比

表-4 外出頻度の要因として用いた変数一覧

\begin{tabular}{|c|c|}
\hline アイテム & カテゴリー \\
\hline $\begin{array}{c}\text { 利用福祉 } \\
\text { 用具 }\end{array}$ & $\begin{array}{l}\text { •車椅子を利用している人 } \\
\text { •その他の福祉用具 } \\
\text { (装具・義足・シルバーカー・歩行器) } \\
\text { を利用している人 } \\
\text { •杖を利用している人 } \\
\text { •福祉用具を利用していない人 }\end{array}$ \\
\hline $\begin{array}{c}\text { 福祉有償運送 } \\
\text { 利用の有無 }\end{array}$ & $\begin{array}{l}\text { •福祉有償運送サービスを利用 } \\
\text { した事がある人 } \\
\text { •福祉有償運送サービスを利用 } \\
\text { した事がない人 } \\
\end{array}$ \\
\hline $\begin{array}{c}\text { 家族の送迎 } \\
\text { の有無 }\end{array}$ & $\begin{array}{l}\text { •自宅居住で家族の送迎のある人 } \\
\text { •自宅居住で家族の送迎のない人 } \\
\text { もしくは,施設居住の人 }\end{array}$ \\
\hline 通所の有無 & $\begin{array}{l}\text { ·通所目的の外出がある人 } \\
\text { ·通所目的の外出がない人 }\end{array}$ \\
\hline 年齢と介護度 & $\begin{array}{l}\text { ·年齢 } 40 \text { 歳未満の人 } \\
\text { ·年齢 } 40 \text { 歳以上で介護度がない人 } \\
\text { ·年齢 } 40 \text { 歳以上で要支援 } \\
\text { もしくは護度 } 1 \cdot 2 \text { } 2 \text { 人 } \\
\text { ·年齢 } 40 \text { 歳以上で介護度 } 3 \text { 以上の }\end{array}$ \\
\hline 通院 & $\begin{array}{l}\text { ·通院目的の外出がある人 } \\
\text { •通院目的の外出がない人 }\end{array}$ \\
\hline
\end{tabular}

べて約 1.4\%増加していることを明らかにした.

\section{4. 移動制約者の外出頻度の要因分析}

\section{（1） 移動制約者の外出頻度}

表-1に示寸調查項目(2)において得られた実際の外出デ 一夕を基に，移動制約者の平均外出間隔を算出した。 そ の結果，平均外出間隔は 3.93 日となり，その值を 1 週間 あたりの外出頻度に換算したところ, 移動制約者の平均 外出頻度は 1.78 回/週となった.

\section{（2）移動制約者の外出頻度の要因分析}

本研究では, 表-4に示寸各アイテムが, 外出頻度に及ぼ す影響の大きさの違いを定量的に把握するために, 数量 化理論 I 類を用いて分析を行った. ここで, 対象サンプ ル数は 86 であり,外的基準には前節で算出した移動制約 者の外出頻度を用いた. アイテムとカテゴリーは表-4に 示寸とおりである. なお,アイテム間の相関については, いずれのアイテム間についても高い相関はなかった.ま た,ここで用いたカテゴリーは, 表-1 に示寸調查項目(2)に おいて得られた外出データと対象となる移動制約者の個 人属性を基に作成したものである. また, 通学目的の外出 は, その要因が他の外出目的と大きく異なるため, 分析対 象から除外している.

分析結果を図-9 に示す. なお, 決定係数は, 0.422 とな っており,まずまずの精度であるといえる. 図-9 に示すよ うに, 移動制約者の外出頻度に最も影響を及ぼしている 要因は, 『通所の有無』であり, 次いで影響を及ぼしてい

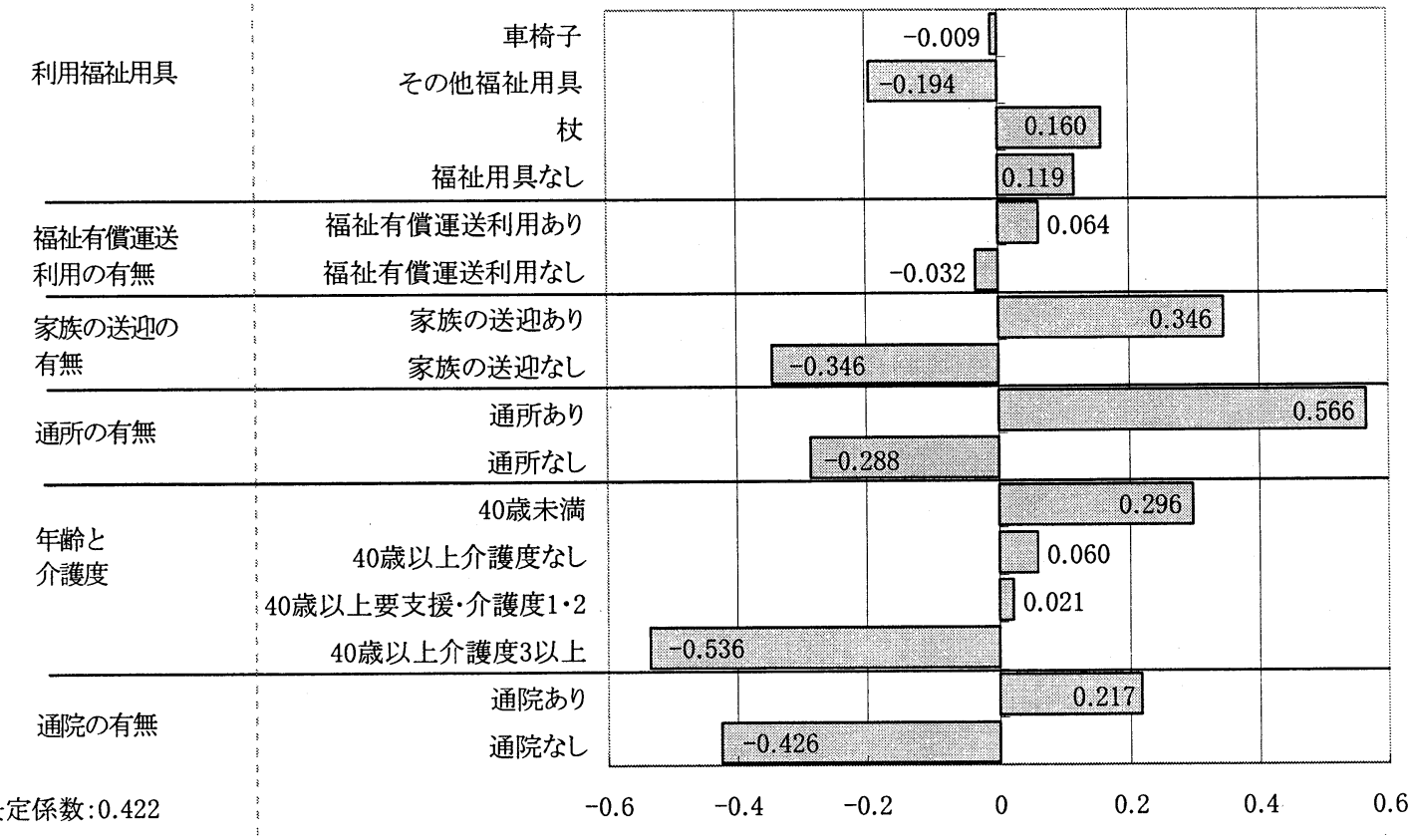

図-9 外出頻度の要因分析 
るのは『年齢と介護度』、家族の送迎の有無』である.

『通所の有無』については, 調查項目(2)において, 通 所目的の外出があると回答した移動制約者の外出頻度は 高くなっており，これは，移動制約者の場合，多くは登 録している事業者でリハビリや介護を受けていると考え られ，通所目的の外出の有無は外出頻度に大きな影響を 及ぼしているためであると考えられる.

『年齢と介護度』については，40 歳未満の移動制約者 は外出頻度が高くなる傾向があり, 40 歳以上で介護度が 高くなるにつれて外出頻度は低くなる傾向がある. 40 歳 以上で介護度が重い移動制約者は, 単独での外出が困難 で介助等が必要となるため, 外出頻度が低くなる傾向に あると考えられる.

『家族の送迎の有無』の場合, 『家族の送迎あり』と回 答した移動制約者の外出頻度は高くなっており，これは 時間的な都合がつき易く, 自由な行動も制限されにくい ためであると考えられる.

最後に, 『福祉有償運送サービス利用の有無』は移動制 約者の外出頻度にあまり影響を与えていないことが明ら かになった.これは, 今回の調査は福祉有償運送サービ 導入後 4 ヶ月の時点で実施しており, 福祉有償運送サ 一ビス導入後の外出増加率は約 $1.4 \%$ と低いことから, 分 析対象となっている外出は福祉有償運送サービス導入以 前から顕在化していた外出であったことがその原因と考 えられる。

\section{5. 福祉有償運送サービス利用の要因分析}

本研究では, 表-5 に示寸各アイテムが福祉有償運送サ 一ビス利用の有無に及ぼす影響の大きさの違いを把握す るために数量化理論II類を用いて分析した.ここで外的 基準には，各事業者の運行記録を基に作成した，移動制 約者個々人の福祉有償運送サービス利用の有無を用いた. 対象サンプル数は 132 である. アイテムとカテゴリーは, 表-5に示すとおりである. なお,アイテム間の相関につい ては,いずれのアイテム間についても, 高い相関はなかっ た.

分析結果を図-10 に示す. なお, 相関比は 0.247 , 的中率 は0.78 との結果となっており,まずまずの精度といえる. 図-10に示すように, 福祉有償運送サービス利用に最も影 響を及ぼしている要因は『事業開始月』であり, 次いで 『年齢と介護度』, 『家族の送迎の有無』である.

『事業開始月』については，8月に事業を開始した事業 者に登録している移動制約者ほど福祉有償運送サービス を利用する傾向にあり, 事業開始が遅い事業者に登録し ている移動制約者ほど福祉有償運送サービスをあまり利 用しない傾向がある. 表-2 に示すように, 8 月に事業を開 始した事業者, 事業開始が遅い事業者のいずれも福祉有
償運送サービス以外に提供しているサービス内容が多岐 にわたっていることから, 提供サービスの内容が福祉有 償運送サービス利用の有無に影響を及ぼしているとは考 えられない.したがって, 福祉有償運送サービス開始から 4 ヶ月しか経過していないが, 事業開始が早い事業者に登 録している移動制約者ほど福祉有償運送サービスが浸透 しつつあるのではないかと考えられる.

『年齢と介護度』については，40 歳以上で比較的介護 度の軽い移動制約者ほど福祉有償運送サービスを利用す る傾向がある. 一方, 40 歳未満の移動制約者は福祉有償 運送サービスをあまり利用しない傾向がある.

また，『家族の送迎の有無』については，家族の送迎が ある移動制約者は福祉有償運送サービスを利用しない傾 向がある.このことからも, 家族に負担はかかるものの， やはり，家族の都合がつく場合は，家族の送迎に頼って いる移動制約者の交通行動の実態を垣間見ることができ る.また, 移動制約者は介助が必要な場合が多く、いつ も介助してもらっている家族の方が安心して介助を依頼 できることも，その理由の一つとして挙げられる.

\section{6. 結論}

本研究で得られた知見を以下に述べる.

『買い物』・娛楽・レジャー』といった外出目的の割 合は, 移動制約者の外出全体に占める割合よりも, 福祉

表-5 福祉有償運送サービス利用の有無 の要因として用いた変数

\begin{tabular}{|c|c|}
\hline アイテム & カテゴリー \\
\hline $\begin{array}{l}\text { 利用福祉 } \\
\text { 用具 }\end{array}$ & $\begin{array}{l}\cdot \text { ·車椅子を利用している人 } \\
\cdot そ の \text { 他の福祉用具 } \\
\text { (装具·義足・シルバーカー・歩行器) } \\
\text { を利用している人 } \\
\text { ·杖を利用している人 } \\
\text { ·福祉用具を利用していない人 }\end{array}$ \\
\hline 事業開始月 & $\begin{array}{l}\cdot .8 \text { 月に事業を開始した事業者 } \\
.9 \text { 月に事業を開始した事業者 } \\
\cdot \text {-10月に事業を開始した事業者 } \\
.12 \text { 月に事業を開始した事業者 } \\
\end{array}$ \\
\hline 年齢と介護度 & 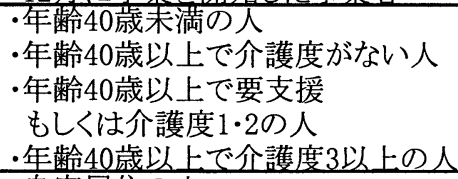 \\
\hline 居住形態 & $\begin{array}{l}\text { ·自宅居住の人 } \\
\text { •施設居住の人 }\end{array}$ \\
\hline $\begin{array}{l}\text { 家族の送迎 } \\
\text { の有無 }\end{array}$ & $\begin{array}{l}\text { •自宅居住で家族の送迎のある人 } \\
\text { ·自宅居住で家族の迎のない人 } \\
\text { もしくは,施設居住の人 }\end{array}$ \\
\hline 通院の有無 & $\begin{array}{l}\cdot \text { ·通院目的の外出がある人 } \\
\text { •通院目的の外出がない人 }\end{array}$ \\
\hline 障害等級 & $\begin{array}{l}\text {-身体障害者手帳の等級がない人 } \\
\text { ·身体障害者手帳の } 3 \text { 級以上の人 } \\
\text { ·身体障害者手帳の } 1 \text {-2級の人 }\end{array}$ \\
\hline
\end{tabular}


有償運送サービスを利用した場合の方が高くなっている. しかし，福祉有償運送サービスを利用した場合の外出に おいても『通院』目的の利用が半数以上を占めているの が現状である. 一方で, 福祉有償運送サービスの導入後 の生活の変化については, 『家族の負担が減った』という 回答が最も多く, 福祉有償運送サービス導入の目的のひ とつである家族負担の軽減については，一定の効果があ ったと考えられる.

移動制約者の外出頻度については, 福祉有償運送サービ スの導入によって約 1.4\%増加していることを明らかに した. そして, 移動制約者の外出頻度に影響している要 因を分析した結果, 最も影響を及ぼしている要因は, 『通 所の有無』であり, 次いで, 『家族の送迎の有無』, とな っており，『福祉有償運送サービス利用の有無』について は, 福祉有償運送サービス導入後 4 ヶ月の時点において は，移動制約者の外出頻度にあまり影響を及ぼしていな いことが明らかになった. さらに, 福祉有償運送サービ ス利用の有無に最も影響を及ぼしている要因は, 『事業開 始月』であり, 事業開始が早い事業者の登録者ほど福祉 有償運送サ一ビスが浸透しつつあると考えられる.

なお, これらの分析結果はいずれも, 福祉有償運送サ 一ビスが導入されてから，わずか 4 ヶ月後に実施した調 査に基づいたものであり, 福祉有償運送サービス導入後 4
ケ月の時点における移動制約者の交通行動の実態につい ては，的確に把握することができたといえる．しかしな がら，導入後わずか 4 ケ月の時点においても，導入時期 が福祉有償運送サービス利用の有無に大きな影響を及ぼ していることからも，ひきつづきデータを収集し，福祉 有償運送サービスの導入が移動制約者の交通行動に及ぼ 寸影響を長期的に把握することは必要不可欠であると考 えられる。

\section{(参考文献)}

1）秋山哲男 : 高齢者・障害者のスペシャルトランスポ 一トサービス, 土木学会論文集 No. 518, IV -28 , pp. 55-67, 1995. 7.

2）溝端光雄 : 高齢者・障害者の移送サービスの統合化 に関する基礎的研究, 土木計画学研究論文 集, No. 15(2), pp. 79-84, 1992. 11.

3）北川博巳, 三星昭宏 : 高齢者モビリティ潜在化の属性 要因と交通需要増加に関する考察, 土木計画学研 究・論文集, No. 15, pp. 747-753, 1998.9.

4）青島縮次郎, 高柳大輔, 伊東弘行 : 身体障害者の顕 在・潜在交通需要比較とそれを踏まえた交通弱者対 応型バスの評価について, 土木計画学研究・論文 集, No. 16, pp. 903-909, 1999. 9.

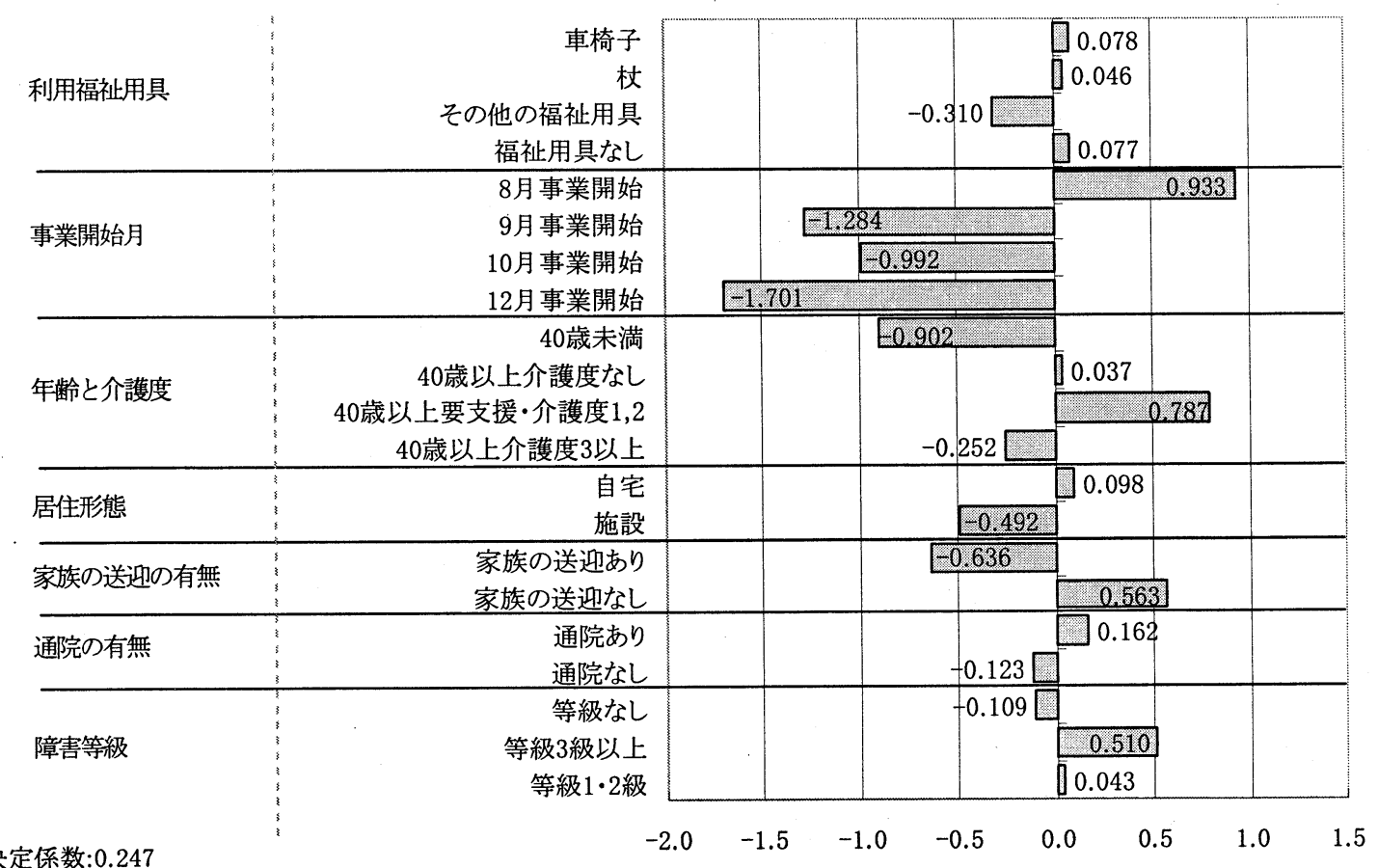

図-10 福祉有償運送サービス利用の要因分析 
高齢者や身体障害者などの移動制約者に対して，公共交通機関を補完する ST サービス導入に対する社会的 要請が高まっており，この状況を打破するために 2003 年 4 月，国の構造改革特別区域の一つとして道路運送 法第 80 条第 1 項の規制が緩和された. そして 2004 年 4 月には, 全国において同法の規制が緩和され移動制約 者を対象とした福祉有償運送サービスが開始された

そこで, 本研究では岡山市・倉敷市において, 福祉有償運送サービスの利用登録者を対象にアンケート調査 を実施し，その結果を用いて移動制約者の外出頻度や福祉有償運送サービス利用の有無に影響を及ぼす交通行 動の要因を実証的に明らかにした.

Factor analysis about travel behavior of the limited mobility people after introduction of special transport service

by Ryoji MATSUNAKA • Mamoru TANIGUCHI • Yuko KUSUDA

The central government authorized all area of Okayama Prefecture as special zones for structural reform in April 2003, and deregulated the ST Service (Special Transport Service) in Okayama Prefecture. Then in 2004, the ST Service was permitted in nationwide.

We conducted the questionnaire to the limited mobility people in Okayama and Kurashiki City where the ST Service has already started. We asked them the purpose of trip, the using transport mode, and the ST Service use. We made empirically clear the factors about travel behavior such as the purpose of trip, and the ST Service use. 